\title{
Algicidal effects of aqueous leaf extracts of neem [Azadirachta indica) on Scenedesmus quadricauda (Turp.) de Brébission
}

\author{
Mathias Ahii Chia ${ }^{12 \star}$, Jamiu Taiwo Akinsanmi², Yahuza Tanimu² and Zakari Ladan ${ }^{3}$
}

Received: June 21, 2015

Accepted: September 28, 2015

\begin{abstract}
The application of synthetic algaecides for the control of algae produces by-products that are sometimes toxic to the environment. There is a need for natural and cheap alternatives to synthetic algaecides. In the present study, we investigated the potential of aqueous crude extract of Azadirachta indica to inhibit the growth of Scenedesmus quadricauda. Phytochemical screening of the extract revealed the presence of groups of bioactive compounds that are capable of inhibiting microalgal growth. Chlorophyll $a$ concentration, dry weight production and cell density of microalga decreased with increasing crude extract concentration. After three days of exposure, the $1000 \mathrm{mg} / \mathrm{L}$ extract concentration resulted in complete growth inhibition and cell lysis. Furthermore, the ability of $S$. quadricauda to form multi-celled coenobial structures was compromised in a concentration dependent manner. In general, catalase and peroxidase activities of the microalga were upregulated with increasing extract concentration. These results imply that aqueous neem extract may provide a cheap and ecofriendly alternative for the control of microalgae in aquatic ecosystems.
\end{abstract}

Keywords: algaecide, growth inhibition, microalgae, Neem, oxidative stress, phenotypic plasticity

\section{Introduction}

The excessive proliferation of cyanobacteria and algae in aquatic ecosystems is controlled by factors such as nutrient composition and concentration, light quality, temperature, water residence time and interspecific competition between phytoplankton groups (Paerl \& Huisman 2009). Chlorophytes on their own are not considered to be nuisance algae, however, nutrient enriched conditions favour the excessive proliferation of members of this group (Paerl et al. 2001). The risk to water quality deterioration is aggravated by the codominance of bloom forming cyanobacteria with members of the green algae. Specifically, there is environmental evidence that Scenedesmus and Microcystis co-dominate or alternate in nutrient enriched freshwater systems due to their vertical migration and ability to form blooms (Huang et al. 2012). Furthermore, the distinctive blooms formed by some members of the chlorophyta constitute serious environmental problems, especially for water treatment facilities and recreational water bodies, because they can cause clogging of filtration equipment, hypoxia, tastes and odours (Reynolds 1984; Paerl et al. 2001; Jeong et al. 2008; Su et al. 2011; Li et al. 2014). Algal management in swimming pools, fish ponds and large water bodies is usually carried out using physical, biological and chemical processes that are usually very expensive or potentially harmful to the environment (Anderson 1997).

The indiscriminate use of synthetic algaecides for chemical control of algae and cyanobacteria leads to environmental contamination, an increase in the level

\footnotetext{
${ }^{1}$ Laboratório de Cianobactérias, Escola Superior de Agricultura Luiz de Queiroz, Universidade de São Paulo, 13418-900, Piracicaba,SP, Brazil

${ }^{2}$ Department of Biological Sciences, Ahmadu Bello University, 810001, Zaria, Nigeria

${ }^{3}$ National Research Institute for Chemical Technology, 810001, Basawa, Zaria, Nigeria

*Corresponding author: chia28us@yahoo.com / machia@usp.br
} 
of toxic residues in aquatic organisms, as well as killing of untargeted aquatic flora and fauna (Su et al. 2011). This necessitates the exploration for cheap biological and environmentally friendly means of tackling this problem. A common approach is to search for bioactive compounds from plants that inhibit or prevent algal growth (Ghorbanian et al. 2008). For example, allelopathic compounds in rice and barley straws have been shown to limit the germination, growth, photosynthesis, respiration and metabolism of other plants including nuisance algae (Park et al. 2006a). While aquatic macrophytes, cyanobacteria and algae have been shown to produce allelochemicals that are capable of inhibiting both cyanobacteria and algae (Chia et al. 2012; Yang et al. 2014; Bittencourt-Oliveira et al. 2014), very little research has been carried out to investigate the algicidal activities of terrestrial plants (Xiao et al. 2011).

Neem extracts contain bioactive constituents that are potent against a large number of pests, and have minimal environmental toxicity because of their rapid degradation in the environment (Isman 2000). Despite the extensive data available on bioactive compounds from neem with pesticidal and medicinal potentials (Gualtieri et al. 2014; Hao et al. 2014), very little is known about their algicidal properties. This study explores the potential of aqueous leaf extract of Azadirachta indica as an eco-friendly and cost effective means of controlling algal growth, using Scenedesmus quadricauda as the test organism. The objective of this study was to determine the algicidal effect of aqueous neem extract on Scenedesmus quadricauda.

\section{Materials and methods}

\section{Microalgal strain}

Experiments were carried out with cultures of the microalga Scenedesmus quadricauda ABU12. The microalga was isolated from a freshwater pond in Zaria, Nigeria (Chia et al. 2011; Chia \& Musa 2014; Chia et al. 2014; 2015) and maintained in OECD medium (OECD 1984). Prior to inoculation with the microalga, the medium was autoclaved at $121^{\circ} \mathrm{C}$ for $30 \mathrm{~min}$ and its $\mathrm{pH}$ adjusted to 7.0. The cultures were maintained at $23 \pm 2^{\circ} \mathrm{C}$ and continuous light $\left(40 \mu \mathrm{mol}\right.$ photons $\left.\mathrm{m}^{-2} \mathrm{~s}^{-1}\right)$ using cool white fluorescent lamps. The reagents used for culture medium preparation were of analytical grade, and were obtained from Sigma Aldrich (USA).

\section{Plant collection and preparation}

Fresh leaves of Azadirachta indica A. Juss were collected, identified and authenticated in the Herbarium of the Department of Biological Sciences, Ahmadu Bello University, Zaria. The leaves were air-dried, crushed and pulverized into fine powder and stored in a glass container at $4^{\circ} \mathrm{C} .250$ $\mathrm{g}$ of the powdered sample was exhaustively extracted with distilled water using reflux method (Trease \& Evans 1989). The mixture was filtered to remove debris. Thereafter, 200 $\mathrm{mL}$ of petroleum ether was added to the mixture, shaken vigorously and allowed to settle. The petroleum ether layer (on top) was removed and concentrated. Afterwards, 200 $\mathrm{mL}$ of chloroform was added to the aqueous layer and also vigorously shaken and allowed to settle. The crude aqueous layer was then concentrated until a brown coloured extract was obtained using mild heat. It was weighed, labelled, and sealed in a plastic container and stored at $-20^{\circ} \mathrm{C}$ until required.

\section{Phytochemical screening}

The presence of bioactive secondary metabolites in the extract was determined using the methods outlined in Sofowora (1993) and Trease \& Evans (2002) (Tab. 1). Furthermore, the presence of potential bioactive secondary metabolites in the extract was confirmed using Fourier

Table 1. Result of phytochemical screening of aqueous extract of Azadirachta indica leaves.

\begin{tabular}{|l|l|l|l|}
\hline \multicolumn{1}{|c|}{ Phytochemicals } & \multicolumn{1}{|c|}{ Test } & \multicolumn{1}{c|}{ Presence/absence } & \multicolumn{1}{c|}{ Reference } \\
\hline Flavonoids & $\begin{array}{l}\text { Shinoda } \\
\text { Sodium hydroxide }\end{array}$ & Present & Trease \& Evans 2002 \\
\hline Saponins & Frothing & Absent & Trease \& Evans 2002 \\
\hline Glycosides & Fehling & Present & Trease \& Evans 2002 \\
\hline Anthraquinones & Borntrager's & Present & Trease \& Evans 2002 \\
\hline Alkaloids & Meyer & Present & Sofowora 1993 \\
\hline Tannins & Ferric chloride & Absent & Trease \& Evans 2002 \\
\hline Steroids & Lieberman Burchard's & Absent & Trease \& Evans 2002 \\
\hline Terpenoids & Lieberman Burchard's & Present & Trease \& Evans 2002 \\
\hline Carbohydrates & Molisch's & Present & Sofowora 1993 \\
\hline Phlobatannins & - & Absent & Trease \& Evans 2002 \\
\hline
\end{tabular}


Transform Infrared (FT-IR) analyses (Williams \& Fleming 2005; Chia et al. 2012). A drop of the aqueous extract was squeezed between flat plates of sodium chloride and scanned from 4000 to $625 \mathrm{~cm}^{-1}$ using a FT-IR Model 8400s Spectrophotometer (Shimadzu, Japan).

\section{Experiments}

Experimental cultures were carried out in $250 \mathrm{~mL}$ Erlenmeyer flask containing $150 \mathrm{~mL}$ of culture media. Exponential phase growing cultures of the green microalga were exposed to different concentrations $(1000 \mathrm{mg} / \mathrm{L}, 100$ $\mathrm{mg} / \mathrm{L}, 10 \mathrm{mg} / \mathrm{L}$ and $1 \mathrm{mg} / \mathrm{L}$ ) of the aqueous extract at an initial density of $10^{5}$ cells $\mathrm{mL}^{-1}$. The control treatment contained $S$. quadricauda growing in BB medium without neem extract addition. The inhibition of $S$. quadricauda growth in relation to the control culture was monitored daily for four days. All experiments were carried out in triplicates.

\section{Growth and Biomass determination}

Aliquots were taken daily for biomass and growth kinetics determination. Growth monitoring was done using microscopic cell counts. Growth inhibition (GI) was calculated as:

$\mathrm{GI}=\left(\mathrm{N}_{\mathrm{c}}-\mathrm{N}_{\mathrm{t}}\right) / \mathrm{Nc} \times 100 \%$ Equation 1

Where $\mathrm{N}_{c}$ is the cell density for the control cultures, and $\mathrm{N}_{\mathrm{t}}$ is the cell density of the treatments.

Dry weight was obtained by filtering $5 \mathrm{~mL}$ of culture on a pre-dried and weighed Sartorius $0.22 \mathrm{uM}$ pore size membrane filter. The residue was weighed to the nearest mg using a digital weighing balance. The extraction and analysis of chlorophyll $a$ were carried out following the procedures outlined by Shoaf \& Lium (1976). Chlorophyll a concentration was determined using the equation given by Németh (1998):

Chlorophyll $a(\mathrm{mg} / \mathrm{L})=\left(17.12^{*} \mathrm{~A}_{663 \mathrm{~nm}}\right)$

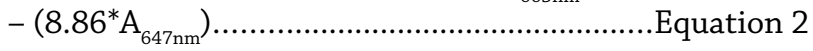

Where $\mathrm{A}_{663 \mathrm{~nm}}$ and $\mathrm{A}_{647 \mathrm{~nm}}$ represent absorbance at 663 and $647 \mathrm{~nm}$, respectively.

\section{Microscopic analyses}

The Improved Neubauer counting chamber was used to determine algal cell density per $\mathrm{mL}$.

Morphological analysis was done by quantifying the number of cells per coenobium per experimental treatment and control using the procedures described in Lombardi $e t$ al. (2007). Coenobia were classified into four categories: four-celled coenobium, three-celled coenobium, two-celled coenobium and free or uni-cells (absence of coenobium).

\section{Antioxidant enzyme activities}

Total protein extraction for antioxidant enzyme assays was done in $0.05 \mathrm{M}$ phosphate buffer ( $\mathrm{pH}$ 7.8). Catalase (EC 1.11.1.6) activity was determined following the method of Luck (1974). One enzyme unit was calculated as the amount of enzyme needed to change the absorbance at $240 \mathrm{~nm}$ by 0.05 units. Peroxidase (EC 1.11.1.11) activity was assayed according to the method of Reddy et al. (1995). The change in absorbance was recorded every 30 seconds for three minutes, and one unit of peroxidase was defined as the change in absorbance per minute at $430 \mathrm{~nm}$.

\section{Data analyses}

Two-way ANOVA was used to determine the differences in mean growth, morphological characteristics and biomass production of $S$. quadricauda under the different experimental conditions tested. Where significant differences were detected, separation of means was done using Tukey's HSD Post Hoc test. ANOVA and Tukey's HSD test were done using Statistica version 8.0 for windows.

\section{Results}

The results of phytochemical screening showed the presences of flavanoids, glycosides, anthraquinones, alkaloids, terpenoids and carbohydrates, while steroids, saponins, phlobatannins and tannins were absent (Tab. 1). FTIR analysis confirmed the presence of different functional groups based on their peak characteristics. These functional groups served as signatures for identifying the presence of bioactive compounds that tested positive in the initial qualitative phytochemical tests. Stretching bond that confirms the presence of primary and secondary amines (-NH) and hydroxyl $(-\mathrm{OH})$ groups $\left(3396.76 \mathrm{~cm}^{-1}\right)$, stretching vibrations specific to $\mathrm{C}-\mathrm{H}\left(1399.40 \mathrm{~cm}^{-1}\right), \mathrm{C}-\mathrm{O}$ stretching for alcohol ethers, esters, carboxylic acids, anhydrides $\left(1066.67 \mathrm{~cm}^{-1}\right)$ and $\mathrm{C}=\mathrm{O}$ carbonyl stretching (with wave numbers between 1800 and $900 \mathrm{~cm}^{-1}$ ) were detected.

Chlorophyll a concentration and cell density decreased with increasing concentrations of aqueous neem extract (Fig. 1A, B). The lowest chlorophyll $a$ concentration and cell density were observed at the highest extract concentration. Dry weight production on the other hand generally decreased with increasing concentrations except for the highest extract concentrations on days 1 and 2. The lowest dry weight production was observed at the 100 mg/L extract treatment (Fig. 1C). These observed differences were statistically significant $(\mathrm{P}<0.05)$ between the treatments for chlorophyll $a$ and cell counts, while for dry weight they were not $(\mathrm{P}>0.05)$ (Tab. 2). From day 3 (72 h) after exposure to the extracts, the highest concentration resulted in complete growth inhibition (Fig. 2). 

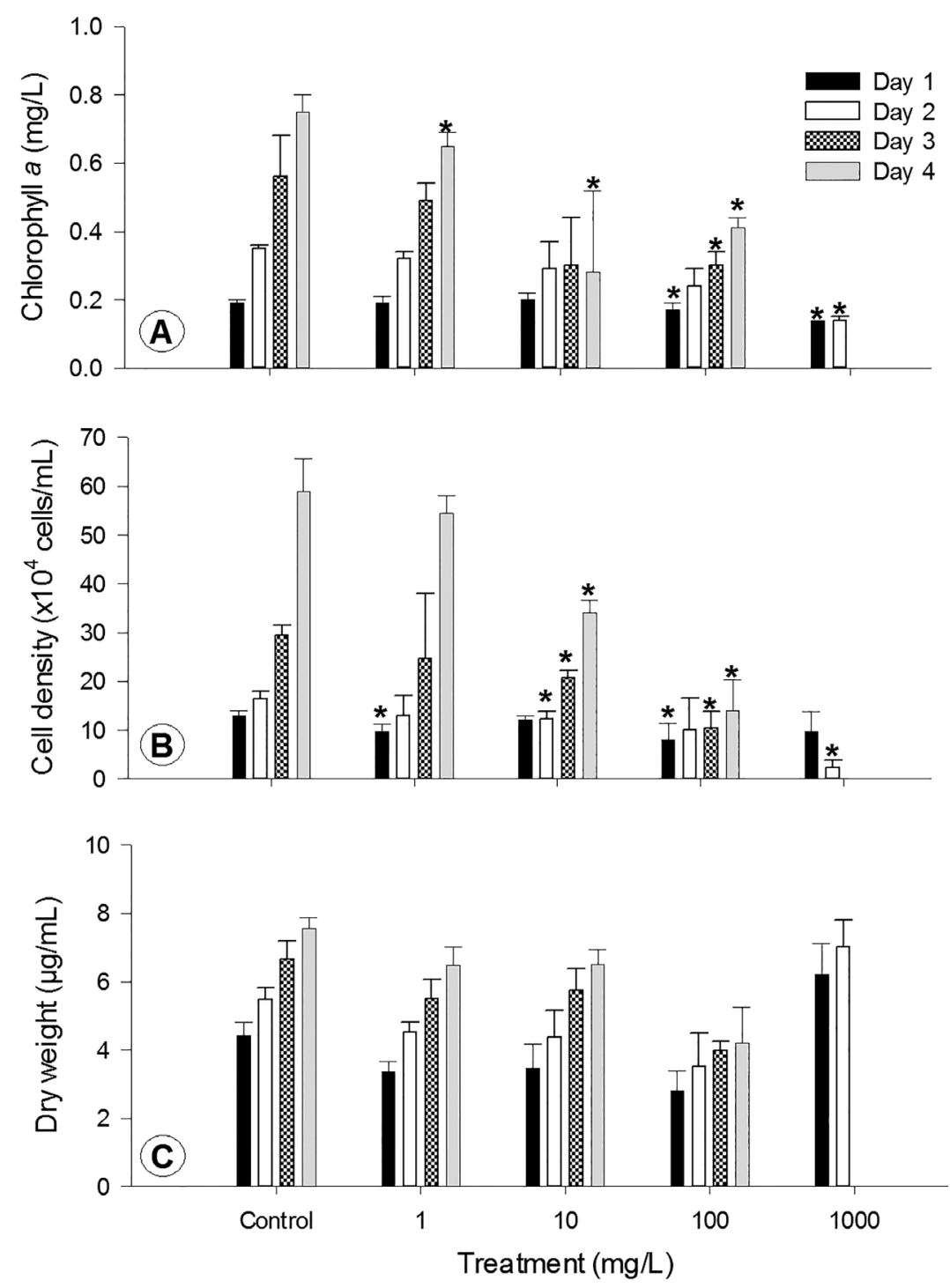

Figure 1. The production of $\mathbf{A}$. chlorophyll $a(\mathrm{mg} / \mathrm{L})$, B. cell counts $\left(\mathrm{x} 10^{4} \mathrm{cells} / \mathrm{mL}\right)$, C. dry weight $(\mu \mathrm{g} / \mathrm{mL})$. Asterisk means the value is significantly different from the control.

Table 2. Analysis of variance summary results for biomass production, phenotypic plasticity and antioxidant enzyme activities of Scenedesmus quadricauda exposed to different concentrations of aqueous neem leaf extracts.

\begin{tabular}{|c|c|c|c|c|c|c|}
\hline & \multicolumn{2}{|c|}{ Treatment } & \multicolumn{2}{|c|}{ Time [days] } & \multicolumn{2}{|c|}{ Treatment vs Time [days] } \\
\hline & F value & Pvalue & F value & P value & F value & Pvalue \\
\hline Cell count & 27.17 & 0.01 & 25.57 & 0.01 & 5.96 & 0.01 \\
\hline Dry weight & 1.18 & 0.3342 & 2.04 & 0.1236 & 1.08 & 0.4014 \\
\hline Chlorophyll a & 60.44 & 0.01 & 1.42 & 0.251 & 1.62 & 0.1236 \\
\hline Peroxidase (POD) & 0.45 & 0.7724 & 3.82 & 0.017 & 0.75 & 0.6915 \\
\hline Catalase (COD) & 5.11 & 0.002 & 19.76 & 0.01 & 3.93 & 0.0005 \\
\hline Free cells & 21.38 & 0.01 & 17.68 & 0.01 & 3.24 & 0.0025 \\
\hline 2 celled-coenobium & 13.37 & 0.01 & 11.9 & 0.01 & 3.48 & 0.0014 \\
\hline 3 celled-coenobium & 10.04 & 0.01 & 6.99 & 0.0007 & 3.14 & 0.0032 \\
\hline 4 celled-coenobium & 14.11 & 0.01 & 7.54 & 0.0004 & 6.79 & 0.01 \\
\hline
\end{tabular}




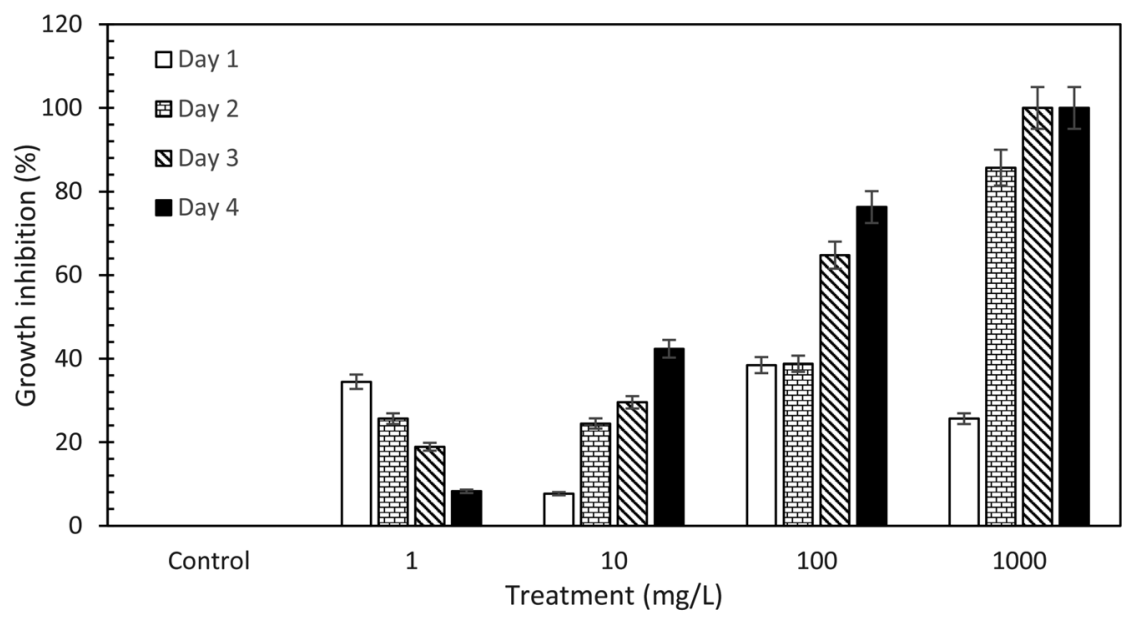

Figure 2. Growth inhibition rate of Scenedesmus quadricauda as a function of different aqueous neem extract concentrations (mg/L).
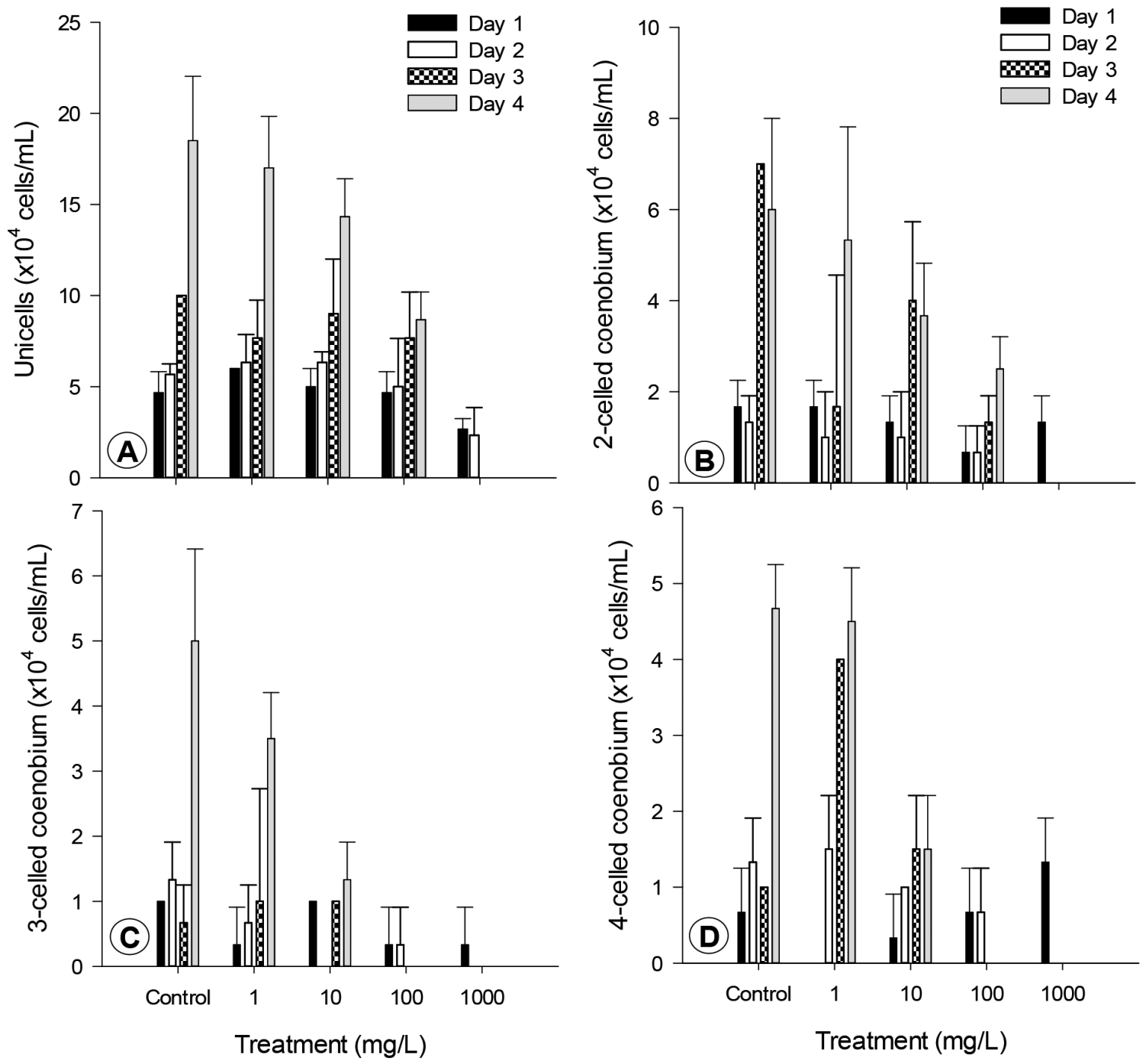

Figure 3. Morphological variation ( $\mathrm{x} 10^{4}$ cells $/ \mathrm{mL}$ ) of Scenedesmus quadricauda after exposure to aqueous extract of Azadirachta indica A. unicells (single cells) B. 2-cells per coenobium C. 3-cells per coenobium D. 4 cells per coenobium. Asterisk means the value is significantly different from the control. 
At the end of the experiment, the highest number of free cells was found in the $1 \mathrm{mg} / \mathrm{L}$ aqueous extract and control treatments (Fig. 3A). Furthermore, the highest extract concentration resulted in almost $100 \%$ growth inhibition with respect to the presence of unicells (free cells) and 2 celled coenobial structures (Fig. 3A-B). The production of 3-and 4-celled coenobia was highest in the control at the end of the experiment (Fig. 3C-D). However, with increasing extract concentration, the number of 3 and 4 celled coenobial structures decreased. The changes in all morphological variants between the treatments and the control were significant $(p<0.05)$. Significant interactions were also observe between treatments and exposure time $(\mathrm{p}<0.05)$ (Tab. 2).

After the first $24 \mathrm{~h}$ of exposure, CAT activity of $S$. quadricauda was higher at all extract concentrations than the control (Fig. 4A). However, at the end of the experiment, almost all the cultures exposed to neem aqueous extracts recorded significant decreases in CAT activity. Peroxidase activity on the other hand increased within the first $72 \mathrm{~h}$ of the exposure of $S$. quadricauda to the extract. However, at the end of the experiment, a general decrease in POD activity was observed in all treatments except the $10 \mathrm{mg} / \mathrm{L}$ treatment (Fig. 4B).

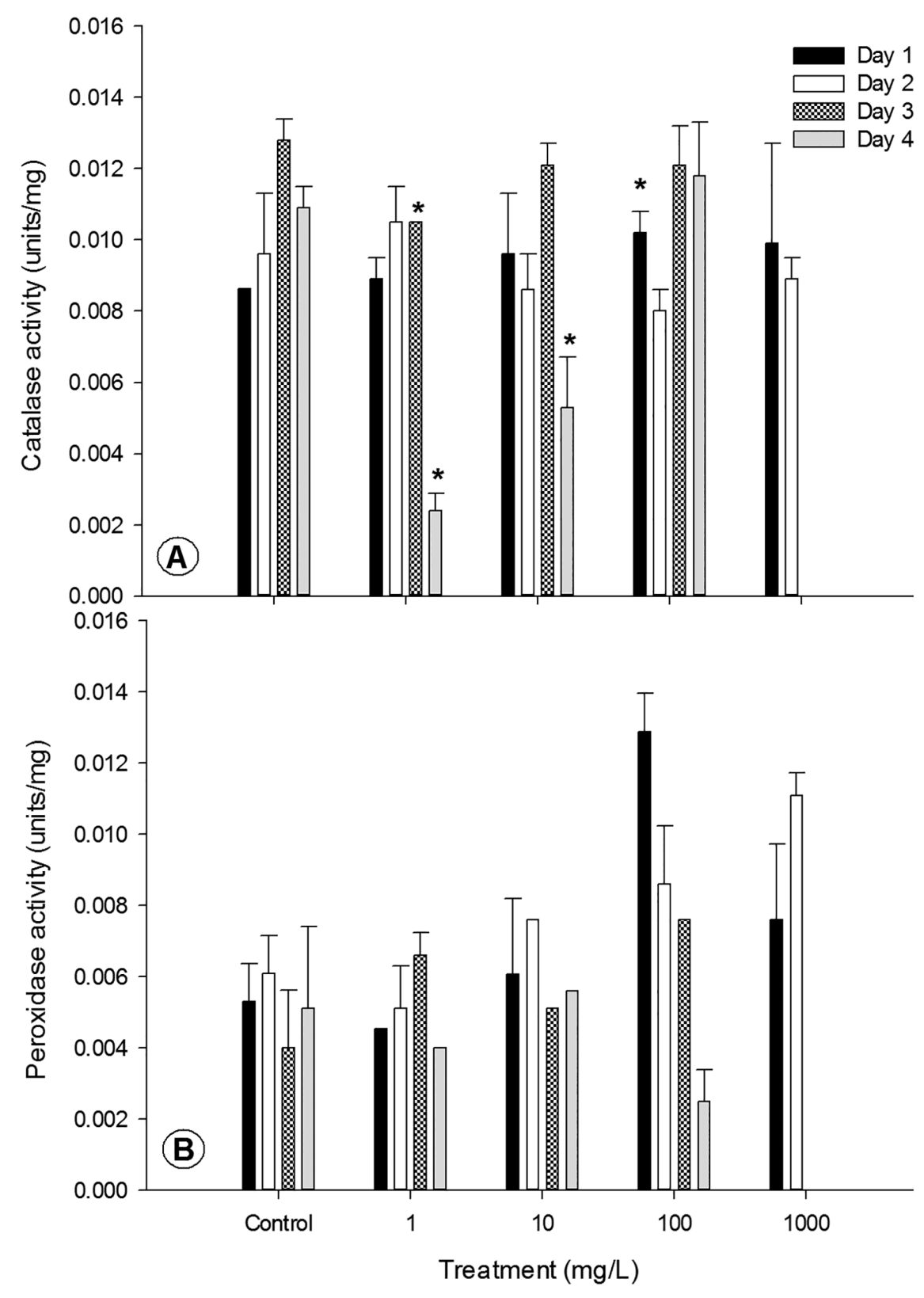

Figure 4. Antioxidant enzyme activities of Scenedesmus quadricauda exposed to different concentrations (mg/L) of aqueous neem leaf extract A. catalase (CAT, units $/ \mathrm{mg}$ ) B. peroxidase (POD, units/mg). Asterisk means the value is significantly different from the control. 


\section{Algicidal effects of aqueous leaf extracts of neem [Azadirachta indica] on Scenedesmus quadricauda [Turp.] de Brébission}

\section{Discussion}

Neem leaf has been reported to possess bioactive compounds which have antiplasmodial, antibacterial, antifungal and antiviral properties (Pillinger et al. 1994; Ferrier et al. 2005). The presence of compounds with potential inhibitory properties was confirmed on the basis of qualitative phytochemical screening. FTIR analysis showed the presence of $\mathrm{C}-\mathrm{O}, \mathrm{C}=\mathrm{O}$, and $-\mathrm{OH}$ in the extract which inferred the presence of carboxylic and terpenoid compounds. Terpenoids are made up of several compounds having varied structural diversity and biological activity (Einhellig 2004). The presence of alkaloids in the aqueous extracts may also be implicated for inhibitory effects. This is because alkaloids have been shown to have some level of allelopathy on plants (Macias et al. 2007). Furthermore, a recent study showed the prospect of amides and amino acids with biological activity in drug synthesis (Lazareva 2011), which means their detection in in our study may have contributed to the algicidal effects observed.

The results of this study showed that aqueous neem extract has algicidal potential because it significantly reduced the biomass (cell number and chlorophyll a) of S. quadricauda. The observed decrease in chlorophyll $a$ content with increasing extract concentration can cause a decrease in the rate of photosynthesis and hamper $\mathrm{CO}_{2}$ assimilation. Consequently, this will negatively affect cell division as there will be no substrate for energy processes and biomolecules synthesis that maintain life processes of the cell. Similar to our results, Ball et al. (2001) and Park et al. (2006b) demonstrated that barley and rice straw inhibited microalgal growth, by limiting germination and normal cell metabolism.

The release of new colony from S. quadricauda mother cells is done in the form of daughter cells with varying number of cells per colony, after unrolling during asexual reproduction (Lürling 2003). Recent studies have shown that this process can be altered when members of the Scenedesmus genus are exposed to stress conditions (PenaCastro et al. 2004; Lombardi et al. 2007; Chia \& Musa 2014; Chia et al. 2015). The resultant decrease in number of cells per coenobium with increasing aqueous neem extract concentration is a demonstration of its bioactivity. The lack of formation multi-celled coenobia at the end of the experiment after exposure to the extract confirms its significant negative effects on the fitness of this microalga.

The excessive production of oxygen radicals during algal metabolism is well reported, especially when they are exposed to toxicants or stress conditions (Zhang et al. 2013). As a result of increased reactive oxygen species (ROS), microalgae tend to up-regulate the biosynthesis and activities of ROS combating enzymes (Chia et al. 2015). The exposure of $S$. quadricauda to neem aqueous extract was not an exception, as it altered the activities of CAT and POD. However, the changes in POD activity were not significant. On the other hand, CAT activity was significantly increased in a concentration dependent manner within the first $48 \mathrm{~h}$ of exposure. This is indicative that the microalga suffered severe oxidative stress with increasing aqueous neem extract concentration. The enzyme represents the first line of defence in plants because it is involved in the decomposition of hydrogen peroxide $\left(\mathrm{H}_{2} \mathrm{O}_{2}\right)$ and superoxide $\left(\mathrm{O}_{2}^{-}\right)$to water and oxygen, by the interaction of the amino acids asparagine at position 147 and histidine at position 74, which causes a proton transfer between the oxygen atoms (Torres et al. 2008). However, we observed that by the $4^{\text {th }}$ day after exposure to the extract, the microalga was no longer able withstand the effect of the extract, as it inhibited CAT activity. The decline in CAT activity may be related to its inactivation via the binding of thiol groups with the bioactive components of the extract investigated (Cordeiro-Araújo et al. 2015). The presence of toxic or bioactive substances in plants induces high production of compounds like nitric oxide and $\mathrm{H}_{2} \mathrm{O}_{2}$, which have the potential to inhibit CAT activity (Clark et al. 2000; Qiao et al. 2014).

In conclusion, the present study showed that aqueous extract of neem is capable of significantly inhibiting the growth of $S$. quadricauda. Cell density and chlorophyll $a$ production were inhibited in the neem extract treatments. However, at the highest extract concentration, there was slight dry weight increase within the first 2 days. Furthermore, aqueous neem extract reduced the ability of S. quadricauda to form multi-celled coenobia or colonies. The extract altered antioxidant enzyme activities of the microalga, indicating the induction of oxidative stress. The presence of potential algicidal groups was confirmed using phytochemical screening. Further studies are needed to isolate and confirm specific molecules from this plant with algicidal properties. However, even without the isolation of specific molecules, these results show that aqueous extract of neem may provide a cheap and safe alternative for preventing excessive microalgal growths in recreational waters like swimming pools, ponds and other aquatic ecosystems. Furthermore, investigations are required to determine the toxicity of these extracts to humans and other organisms.

\section{References}

Anderson DM. 1997. Turning back the harmful red tide. Nature 338: 513-514.

Ball AS, Williams M, Vincent D, Robinson J. 2001. Algal growth control by a barley extract. Bioresource Technology 77: 177-181.

Bittencourt-Oliveira MC, Chia AM, Oliveira HSB, Araújo MKC, Molica RJR, Dias CTS. 2014. Allelopathic interactions between microcystinproducing and non-microcystin-producing cyanobacteria and green microalgae: implications for microcystins production. Journal of Applied Phycology 27: 275-284.

Chia AM, Adelanwa MA, Ladan Z, Iortsuun DN, Adanyi SE, Stephen BJ. 2012. Interactions of Ipomoea aquatica and Utricularia reflexa with phytoplankton densities in a small water body in northern Nigeria. Oceanological and Hydrobiological Studies 41: 39-47. 
Chia AM, Bako SP, Alonge SO, Adamu AK. 2011. Green algal interactions with physicochemical parameters of some manmade ponds in Zaria, northern Nigeria. Brazilian Journal of Botany 34: 285-295.

Chia AM, Chimdirim PK, Japhet WS. 2015. Lead induced antioxidant response and phenotypic plasticity of Scenedesmus quadricauda (Turp.) de Brébisson under different nitrogen conditions. Journal of Applied Phycology 27: 293-302.

Chia AM, Musa IR. 2014. Effect of indigo dye effluent on the growth, biomass production and phenotypic plasticity of Scenedesmus quadricauda (Chlorococcales). Anais da Academia Brasileira de Ciências 86: 419-428.

Chia AM, Odoh OA, Ladan Z. 2014. The indigo blue dye decolorization potential of immobilized Scenedesmus quadricauda. Water, Air and Soil Pollution 225: 1920.

Clark D, Durner J, Navarre DA, Klessig DF. 2000. Nitric oxide inhibition of tobacco catalase and ascorbate peroxidase. Molecular Plant-Microbe Interactions 13: 1380-1384.

Cordeiro-Araújo MK, Chia AM, Hereman TC, Sasaki FF, BittencourtOliveira MC. 2015. Selective membrane permeability and peroxidase activity response of lettuce and arugula irrigated with cyanobacterial contaminated water. Environmental Earth Sciences 74: 1547-1553.

Einhellig FA. 2004. Mode of allelochemical action of phenolic compounds. In: Macías FA, Galindo JCG, Molinillo JMGV, Cutler HG (eds.) Allelopathy: Chemistry and Mode of Action. Boca Raton, CRC Press. p. 217-238.

Ferrier MD, Butler BR, Terlizzi DE, Lacouture RV. 2005. The effects of barley straw (Hordeum vulgare) on the growth of freshwater algae. Bioresource Technology 96: 1788-1795.

Ghorbanian M, Razzaghi-Abyaneh M, Allameh A, Shams-Ghahfarokhi M, Qorbani M. 2008. Study on the effect of neem (Azadirachta indica) leaf extract on the growth of Aspergillus parasiticus and production of aflatoxins by it at different incubation times. Mycoses 51: 35-39.

Gualtieri MJ, Malfronte N, Vassalo A, et al. 2014. Bioactive Limonoids from the leaves of Azaridachta indica (Neem). Journal of Natural Products 77: 596-602.

Hao F, Kumar S, Yadav N, Chandra D. 2014. Neem components as potential agents for cancer prevention and treatment. BBA - Nature Reviews Cancer 1846: 247-257.

Huang YL, Zhang P, Zhu C, Zhou ZH. 2012. Vertical migration comparison of Scenedesmus and Microcystis. Advanced Materials Research 518-523: 558-564.

Isman MB. 2000. Biopesticides based on Phytochemical Biopesticides. Amsterdam, Overseas Publishers Association.

Jeong HJ, Kim JS, Yoo YD, et al. 2008. Control of the harmful alga Cochlodinium polykrikoides by the naked ciliate Strombidinopsis jeokjo in mesocosm enclosures. Harmful algae 7: 368-377.

Lazareva NF. 2011. N-(Silylmethyl)amines, -amides, and -amino acids: biological activity and prospects in drug synthesis. Russian Chemical Bulletin, International Edition 60: 615-632.

Li D, Zhang H, Fu L, et al. 2014. A Novel Algicide: Evidence of the Effect of a Fatty Acid Compound from the Marine Bacterium, Vibrio sp. BS02 on the Harmful Dinoflagellate, Alexandrium tamarense. PLoS ONE 9(3): e91201.

Lombardi AT, Hidalgo TMDS, Viera AAH, Sartori AL. 2007. Toxicity of ionic copper to freshwater microalga Scenedesmus acuminatus (Chlorophyceae, Chlorococcales). Phycologia 46: 74-78.

Luck H. 1974. In: Methods in enzymatic analysis 2 (ed. Bergmeyer), Academic Press New York. P.885.

Lürling M. 2003. Phenotypic plasticity in the green algae Desmodesmus and Scenedesmus with special reference to the induction of defensive morphology. Annales de Limnologie 39: 85-101.

Macias FA, Molinillo MGJ, Varela RM, Galindo JCG. 2007. Allelopathy - a natural alternative for weed control. Pest Management Science 63: 327-348.
Németh J. 1998. A biológiai vízminősítés módszerei. Környezetgazdálkodási Intézet. Budapest, TOI Környezetvédelmi Tájékoztató Szolgálat.

OECD - Organization for Economic Co-operation and Development. 1984. Alga growth inhibition test. OECD Guideline for Testing of Chemicals 201, France.

Paerl HW, Fulton RS, Moisander PH, Dyble J. 2001. Harmful freshwater algal blooms, with an emphasis on cyanobacteria. The Scientific World 1: 76-113.

Paerl HW, Huisman J. 2009. Climate change: a catalyst for global expansion of harmful cyanobacterial blooms. Environmental Microbiology Reports 1: 27-37.

Park MH, Hwang SJ, Ahn CY, Kim BH, Oh HM. 2006a. Screening of seventeen oak extracts for the growth inhibition of the cyanobacterium Microcystis aeruginosa Kutz. em. Elenkin. Bulletin of Environmental Contamination and Toxicology 77: 9-14.

Park MH, Han MS, Ahn CY, Kim HS, Yoon BD, Oh HM. 2006b. Growth inhibition of bloom-forming cyanobacterium Microcystis aeruginosa by rice straw extract. Letters in Applied Microbiology 43: 307-312.

Pena-Castro JM, Martinez-Jeronimo F, Esparza-García F, Canizares-Villanueva RO. 2004. Phenotypic plasticity in Scenedesmus incrassatulus (Chlorophyceae) in response to heavy metal stress. Chemosphere 57: 1629-1636.

Pillinger JM, Cooper JA, Ridge I. 1994. Role of phenolic compounds in the antialgal activity of barley straw. Journal of Chemical Ecology 20: 1557-1569.

Qiao W, Li C, Fan LM. 2014. Cross-talk between nitric oxide and hydrogen peroxide in plant responses to abiotic stresses. Environmental and Experimental Botany 100: 84-93.

Reddy JK, Suga T, Mannaerts GP, Lazarow PB, Ubramani SS. 1995 Peroxisomes: Biology and role in toxicology and disease. New York, Annals of the New York Academy of Sciences 840: 1-795.

Reynolds CS. 1984. The Ecology of Freshwater Phytoplankton. Cambridge, Cambridge University Press.

Shoaf WT, Lium BW. 1976. Improved extraction of chlorophyll-a and -b from algae using dimethylsulfoxide. Limnology and Oceanography 21: 926-928.

Sofowora A. 1993. Medicinal plants and Traditional medicine in Africa. Ibadan, Spectrum Books Ltd.

Su J, Yang X, Zhou Y, Zheng TL. 2011. Marine bacteria antagonistic to the harmful algal bloom species Alexandrium tamarense (Dinophyceae). Biological Control 56: 132-138.

Torres MA, Barros MP, Campos SCG, et al. 2008. Biochemical biomarkers in algae and marine pollution: a review. Ecotoxicology and Environmental Safety 71:1-15

Trease GE, Evans WC. 1989. A textbook on pharmacognosy, 11th. edn. London, Bailliere Tindal.

Trease GE, Evans WC. 2002. Pharmacognosy. London, Saunders Publishers.

William DH, Fleming I. 2005. Spectroscopic methods in organic chemistry. 5th. edn. Delhi, Tata McGraw-Hill.

Xiao NIL, Yang HAOX, Yin LIS, Jin CS, Xiang RG, Liang Z. 2011. Inhibitory effects of the extracts with different solvents from three compositae plants on cyanobacterium Microcystis aeruginosa. Science China Chemistry 54: 1123-1129.

Yang Z, Kong F, Shi X, Yu Y, Zhang M. 2014. Effects of UV-B radiation on microcystin production of toxic strain of Microcystis aeruginosa and its competitiveness against a non-toxic strain. Journal of Hazardous Materials 283: 447-453.

Zhang W, Xiong B, Chen L, et al. 2013. Toxicity assessment of Chlorella vulgaris and Chlorella protothecoides following exposure to $\mathrm{Pb}$ (II). Environmental Toxicology and Pharmacology 36: 51-57. 